\title{
Making music with bayesvl
}

\author{
Manh-Toan Ho \\ ISR, Phenikaa University \\ Hanoi, 20-07-2021
}

So, Bản hòa tâu dũ liệu xã hội [1] is finally published (See the cover in Figure 1). This is officially my first book, so I feel like there should be something to mark the occasion.

The book, essentially, is an in-depth guideline of how to use bayesv/-a program focuses on Bayesian statistics from Vuong Quan Hoang and La Viet Phuong $[2,3]$. The core idea of the bayesv/ project, explaining more thoroughly in several papers [4-6], is to provide an easy-to-use software that will enable users to understand and use Bayesian statistics. Moreover, the software also focuses on the visualization of data analysis and a specific pedagogical goal of teaching Bayesian statistics.

In truth, I took no part in the conceptualization (which was way over my head), or the construction (which was also way over my head) of the bayesv/ R package. However, having the chance to use the package early, I have learned about Bayesian statistics and started applying the method to my works. So, the book cannot be without you, Dr. Vuong, and Dr. La. Thank you!

Figure 1. The cover of Bản hòa tấu dũ̃ liệu xã hội

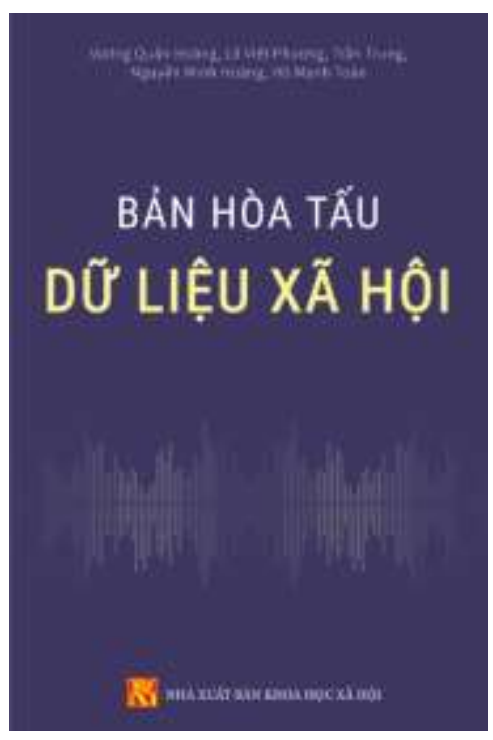


In a larger context, the book [1] is our first attempt to produce a thorough document and training programs for learners and practitioners of Bayesian statistics and the bayesv/ package. The book was written in Vietnamese for a simple reason: The authors are Vietnamese. However, we also believe that the bayesv/ package can meaningfully contribute to the development of Vietnam's social sciences and humanities. In the future, we hope to publish an English version soon.

One of the sweet things about the book is the title: Bản hòa tấu dữ liệu xã hội (The concert of social data). In the entertainment industry, artists have been trying to play with audiences' expectations by mashing genres or experimenting with different formats. In a way, Bản hòa tấu dữ liệu xã hội is also our way of avoiding the usual highly technical title of a statistics book. In the book, we make a direct connection between the images that bayesv/produces and the sheet music.

A book is usually the end of a research project. Meanwhile, Bản hòa tâu dữ liệu xã hội is the beginning of an exciting and long-term project. I am happy to be a part of.

\section{References}

[1] Hoàng VQ, Phương LV, Trung T, Hoàng NM, Toàn HM. (2021). Bản hòa tấu dữ liệu xã hội. Nxb Khoa học Xã hội, Hà Nội. ISBN: 978-604-308-549-5. Available at: https://books.google.com/books/?id=eBU5EAAAQBA]

[2] La VP, \& Vuong QH. (2019). bayesvl: Visually learning the graphical structure of Bayesian networks and performing MCMC with 'Stan'. The Comprehensive $R$ Archive Network (CRAN). Available at: https://cran.rstudio.com/web/packages/bayesvl/index.html

[3] Vuong QH, \& La VP. (2019). BayesVL package for Bayesian statistical analyses in R. github. Available at: https://github.com/sshpa/bayesvl

[4] Vuong QH, La VP, Nguyen MH, Ho MT, Ho MT, \& Mantello P. (2020). Improving Bayesian statistics understanding in the age of Big Data with the bayesvl $\mathrm{R}$ package. Software Impacts, 4, 100016.

[5] Vuong QH, La VP, Nguyen MH, Ho MT, Tran T, \& Ho MT. (2020). Bayesian analysis for social data: A step-by-step protocol and interpretation. MethodsX, 7, 100924.

[6] Vuong QH, Ho TM, La VP. (2019). 'Stargazing' and p-hacking behaviours in social sciences: some insights from a developing country. European Science Editing, $45(2), 56-57$. 